Lattice Parameter of Beta Titanium at Room Temperature

\title{
by B. W. Levinger
}

$T$ HE lattice parameter of the $\beta$ form of pure titanium has been measured at elevated temperature., ${ }^{1,2}$ No attempt was made, however, to correct the parameter obtained to room temperature.

In the course of phase diagram studies at Armour Research Foundation and elsewhere, the variation of $\beta$-phase lattice parameter with composition has been established in a number of binary and ternary systems involving titanium. It was possible to extrapolate in these instances to $100 \mathrm{pct} \mathrm{Ti}$ to find the apparent lattice parameter of $\beta$ titanium at room temperature. Table I lists the results thus obtained. The suggested value for the lattice parameter of $\beta$ titanium is the average of the extrapolated values $3.276 \pm 0.003 \mathrm{kX}$. This suggested value gives an interatomic distance in $\beta$ titanium of $2.837 \mathrm{kX}$ and

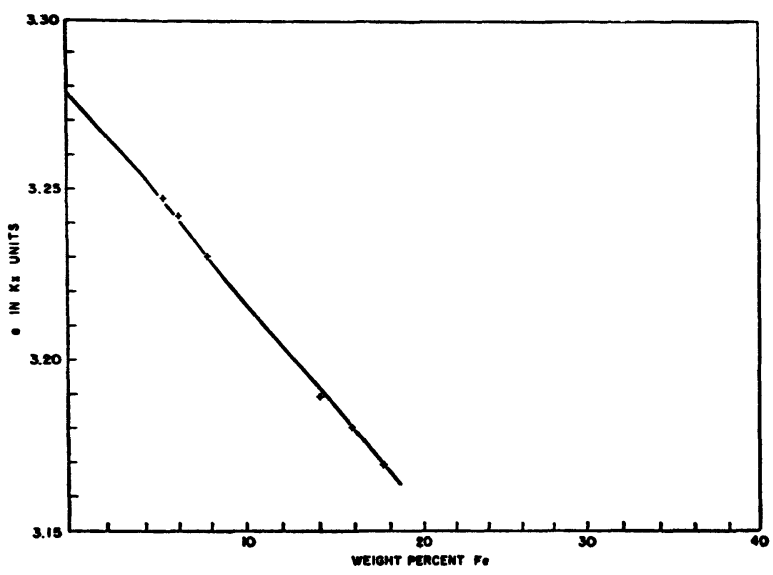

Fig. 1-Lattice parameter vs composition of $\beta$ phase in binary Ti-Fe alloys.

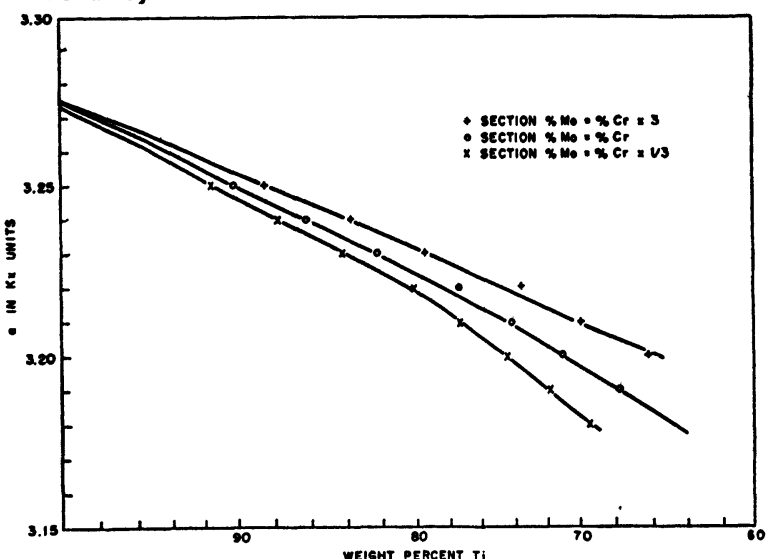

Fig. 2-Lattice parameter vs composition of $\beta$ phase in ternary $\mathrm{Ti}-\mathrm{Mo}-\mathrm{Cr}$ alloys.

hence a Goldschmidt atomic diameter (coordination number 12) of $2.925 \mathrm{kX}$. The latter agrees closely with the value of 2.93 given by Hume-Rothery.

From the data of Adenstedt and coworkers ${ }^{4}$ it was possible to determine by extrapolation the mean coefficient of linear expansion for $\beta$ titanium in the range from room temperature to $1000^{\circ} \mathrm{C}$. This value, $10.1 \times 10^{-6}$ per degree $C$, compares with about $11 \times 10^{-6}$

B. W. LeVINGER, Junior Member AIME, is Assistant Metallurgist, Metals Research Department, Armour Research Foundation of Illinois Institute of Technology, Chicago.

TN 138E. Manuscript, Aug. 27, 1952.
Table 1. Apparent Lattice Parameter of Beta Titanium at Room Temperature

\begin{tabular}{lccc}
\hline & $\begin{array}{c}\text { Extrapolated } \\
\beta \text { Phase } \\
\text { Parameter } \\
(\mathbf{k X )}\end{array}$ & $\begin{array}{c}\text { Limit of } \\
\text { Stable } \\
\boldsymbol{\beta} \text { Phase } \\
\text { Wt Pet Ti }\end{array}$ & Reference \\
\hline Ti-V & 3.275 & 85 & 4 \\
Ti-Cr & 3.28 & 85 & 6 \\
Ti-Mo & 3.278 & 94 & 7 \\
Ti-Nb & 3.276 & 90 & 8 \\
Ti-Fe & 3.276 & 64 & 8 \\
Ti-Mo-Cr & 3.278 & 96 & 9 \\
Ti-Mo-Mn & 3.275 & & 9 \\
\hline
\end{tabular}

for $\alpha$ titanium in a similar range. ${ }^{5}$ It was thus possible to calculate the parameter at $900^{\circ} \mathrm{C}$. The value of $3.305 \mathrm{kX}$ agrees well with 3.3065 given by Eppelsheimer. ${ }^{2}$

The majority of values reported in the literature ${ }^{1-4,8}$ were given as Angstroms. In at least one case, ref. 8, it was shown that they actually represented $\mathrm{kX}$ units. The source of this confusion appears to be that a large number of tables of X-ray emission spectra list wavelengths as Angstroms and give values in $\mathrm{kX}$ units. The accepted conversion factor for $\mathrm{kX}$

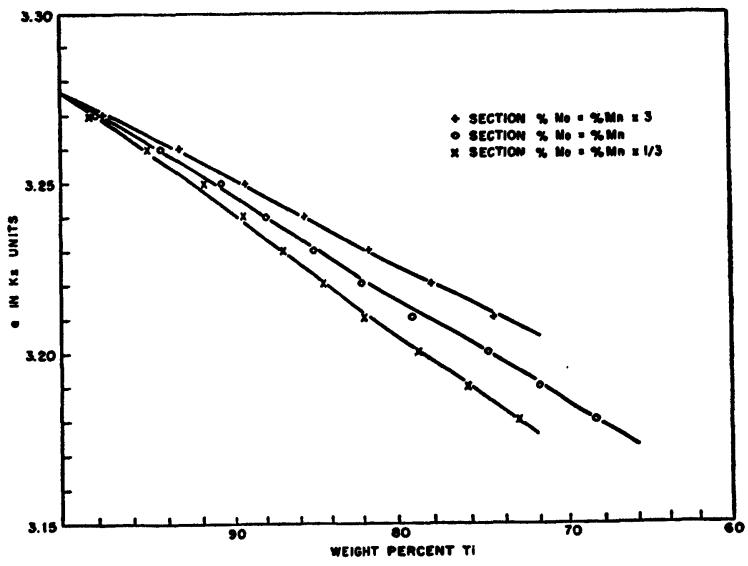

Fig. 3-Lattice parameter vs composition of $\beta$ phase in ternary $\mathrm{Ti}-\mathrm{Mo}_{0}-\mathrm{Mn}$ alloys.

units to Angstroms $\left(10^{-8} \mathrm{~cm}\right)$ is 1.00202 . Thus the parameter of $\beta$ titanium suggested corresponds to $3.282 \AA$.

\section{References}

${ }^{1}$ J. H. de Boer, W. G. Burgers, and J. D. Fast: Proc. Acad. Amsterdam (1936) 39, p. 515.

${ }^{2}$ D. S. Eppelsheimer and R. R. Penman: Nature (Dec. 2, 1950) 166, p. 960 .

${ }^{3} \mathrm{~W}$. Hume-Rothery: The Structure of Metals and Alloys (1945) London. Inst. Metals.

${ }^{4} \mathrm{H}$. K. Adenstedt, J. R. Pequignot, and J. M. Raymer: Trans. ASM (1952) 44, p. 990.

${ }^{5}$ Gmelins Handbuch der Anorganischen Chemie. Titan, Verlag Chemie, Weinhein (1951).

${ }^{\circ}$ P. Pietrokowsky and P. Duwez: Trans. AIME (1952) 194, p. 627; Journal of Metals (June 1952).

${ }^{7} \mathrm{P}$. Duwez and J. L. Taylor: Trans. ASM (1952) 44, p. 495.

${ }^{8}$ M. Hansen, E. L. Kamen, H. D. Kessler, and D. J. McPherson: Trans. AIME (1951) 191, p. 881; JouRNAL of Metals (October 1951).

'Unpublished Research, Armour Research Foundation. 